\title{
Effect of Activated Carbon Addition with Enhance Performance on a Membrane Bioreactor (MBR)
}

\author{
Wimonmas Boonyungyuen and Boonchai Wichitsathian
}

\begin{abstract}
The paper aims at studying the effect of activated carbon (AC) on pollutant removal and filtration performance of Hybrid Membrane Bioreactor (HMBR) were operated at hydraulic retention time of $24 \mathrm{~h}$. under the textile wastewater treated by anaerobic digestion. AC addition led to TMP decrease for the rate of HMBR system to about twice the rate of the MBR system. The irreversible fouling of HMBR was 2 times lower than MBR system, where the decrease was mainly caused by the cake resistance reduction. In addition, foulant found in HMBR system was $\mathbf{9 . 1 2} \%$ lower than MBR system because AC can absorb foulant. The removal efficiencies of HMBR were higher than MBR system. The TKN removal of HMBR system is higher than MBR at $14.2 \%$. This is due to the biofilm on AC surface which allows anoxic condition inside porous biofilm and enhances nitrite/nitrate removal efficiency.
\end{abstract}

Index Terms-Activated carbon, membrane bioreactor, membrane fouling, filtration performance, nitrification-Denitrification rate.

\section{INTRODUCTION}

The application of a submerged membrane bioreactor (SMBR) is widely recognized for its innovative contribution to wastewater treatment processes. SMBR has more advantages than conventional treatment methods such as being more stable and having better effluent quality, possibly supporting high volumetric load and haveing less surplus sludge production [1], [2]. However, SMBR has the problem of membrane fouling, which decreases the permeate flux and leads to frequent cleaning and replacing membrane. Membrane fouling can be divided into 2 parts, external fouling due to cake formation through the attachment of microbial cells and the deposition of inorganic matter on the membrane surface and internal fouling due to fine colloids clogging and dissolved organics adsorption in membrane pore [3]. Preventing membrane fouling will reduce cake layer on membrane surfaces when SMBR is operated at subcritical flux [4], [5], air-scouring, relaxing, backwashing modifying the membrane surface and the addition of activated carbon. Addition of activated carbon (AC) contributes to flux enhancement due to physical scouring of the membrane surface and also improves organics removal by adsorption of dissolved organics [6], [7]. However, the effect of activated carbon on the improvements of submerged membrane bioreactor performance is not clear. This study was designed to understand the effect of activated carbon on the performance of SMBR system and wastewater treatment system.

Manuscript received April 13, 2013; revised July 12, 2013

The authors are with School of Environmental Engineering, Institute of Engineering, Suranaree University of Technology, Nakhon Ratchasima, 30000, Thailand (e-mail: bwimonmas@yahoo.com, boonchai@sut.ac.th).

\section{MATERIALS AND METHOD}

\section{A. Synthetic Textile Wastewater and Activated Carbon}

Synthetic textile wastewater was prepared using desizing, scouring bleaching, mercerizing, dyeing and finishing process in textile industry. The components of the synthetic dyeing wastewater included $100 \mathrm{mg} / \mathrm{L}$ reactive red 141 dye obtained from DyStar Thai Co., Ltd. Thailand., $900 \mathrm{mg} / \mathrm{L}$ starch, $150 \mathrm{mg} / \mathrm{L}$ polyvinyl alcohol (PVA), $50 \mathrm{mg} / \mathrm{L}$ polyarcylic acid and $110 \mathrm{mg} / \mathrm{L} \mathrm{NaOH}$, nutrients: $67 \mathrm{mg} / \mathrm{L}$ $\mathrm{KH}_{2} \mathrm{PO}_{4}, 26 \mathrm{mg} / \mathrm{L} \mathrm{CaCl} 2 \cdot 2 \mathrm{H}_{2} \mathrm{O}, 28 \mathrm{mg} / \mathrm{L} \mathrm{MgSO}{ }_{4} \cdot 7 \mathrm{H}_{2} \mathrm{O}$ and $6 \mathrm{mg} / \mathrm{L} \mathrm{FeCl}_{3} \cdot 6 \mathrm{H}_{2} \mathrm{O}$ and $1 \mathrm{ml} / \mathrm{L}$ of a trace element solution containing $5000 \mathrm{mg} / \mathrm{L} \mathrm{FeSO}_{4} \cdot 7 \mathrm{H}_{2} \mathrm{O}, 392 \mathrm{mg} / \mathrm{L} \mathrm{CuSO}_{4} \cdot 7 \mathrm{H}_{2} \mathrm{O}$, $248 \mathrm{mg} / \mathrm{L} \mathrm{Co}\left(\mathrm{NO}_{3}\right)_{2} \cdot 6 \mathrm{H}_{2} \mathrm{O}, 177 \mathrm{mg} / \mathrm{L} \mathrm{NaB}_{4} \mathrm{O}_{7} \cdot 10 \mathrm{H}_{2} \mathrm{O}, 100$ $\mathrm{MnCl}_{2} \cdot 4 \mathrm{H}_{2} \mathrm{O}, 25 \mathrm{mg} / \mathrm{L} \quad \mathrm{NiCl}_{7} \cdot 6 \mathrm{H}_{2} \mathrm{O}$ and $11 \mathrm{mg} / \mathrm{L}$ $\mathrm{ZnSO}_{4} \cdot 7 \mathrm{H}_{2} \mathrm{O}$. The characteristics of the synthetic textile wastewater are shown in Table I.

TABLE I: TEXTILE WASTEWATER CHARACTERISTICS
\begin{tabular}{|l|c|}
\hline Parameters & Values \\
\hline $\mathrm{TCOD}(\mathrm{mg} / \mathrm{L})$ & $1000 \pm 58$ \\
\hline $\mathrm{SCOD}(\mathrm{mg} / \mathrm{L})$ & $714 \pm 41$ \\
\hline $\mathrm{TBOD}_{20}(\mathrm{mg} / \mathrm{L})$ & $150.1 \pm 5.9$ \\
\hline $\mathrm{SBOD}_{20}(\mathrm{mg} / \mathrm{L})$ & $107.2 \pm 1.5$ \\
\hline $\mathrm{TKN}(\mathrm{mg} / \mathrm{L}$ as $\mathrm{N})$ & $8.8 \pm 1.3$ \\
\hline $\mathrm{TP}(\mathrm{mg} / \mathrm{L})$ & $5.0 \pm 0.2$ \\
\hline Color $(\mathrm{ADMI})$ & $2179.7 \pm 88.0$ \\
\hline
\end{tabular}

Activated carbon was washed with distilled water and dried at $105^{\circ} \mathrm{C}$ for 24 hours. The particle size of activated carbon used was $0.425-0.600 \mathrm{~mm}$; measured using dry sieving process. The activated carbon was added in MBR system at different concentrations according to Equation (1) [8] for hybrid membrane bioreactor (HMBR).

$$
X_{P}=X_{I}\left(\frac{\mathrm{SRT}}{\mathrm{HRT}}\right)
$$

$X_{P}$ is the equilibrium concentration of MLVSS and activated carbon $(\mathrm{mg} / \mathrm{L}), X_{I}$ is concentration of activated carbon $(\mathrm{mg} / \mathrm{L})$, SRT is sludge retention time (day) and HRT is hydraulic retention time (day).

\section{B. Experimental Setup}

The experimental setup used for this study is shown in Fig. 1. The two-stage system consists of an anaerobic digestion and an aerobic MBR. The anaerobic system contained $20 \mathrm{~L}$ of working volume. The aerobic MBR part was used for comparing HMBR and MBR. The MBR used had a working volume of $10 \mathrm{~L}$ and contained a hollow fiber membrane $(0.9$ $\mathrm{m}^{2}, 0.4 \mu \mathrm{m}$ pore size and polycrylonitrile) with added PAC 
of $715 \mathrm{mg} / \mathrm{L}$. The effluent stream was controlled by a peristaltic pump maintained a flow rate based on HRT 1 day. The flux was measured using a calibrated cylinder and a stopwatch. The transmembrane pressure (TMP) was measured using vacuum gauge with monitoring pressure difference across the membrane module.

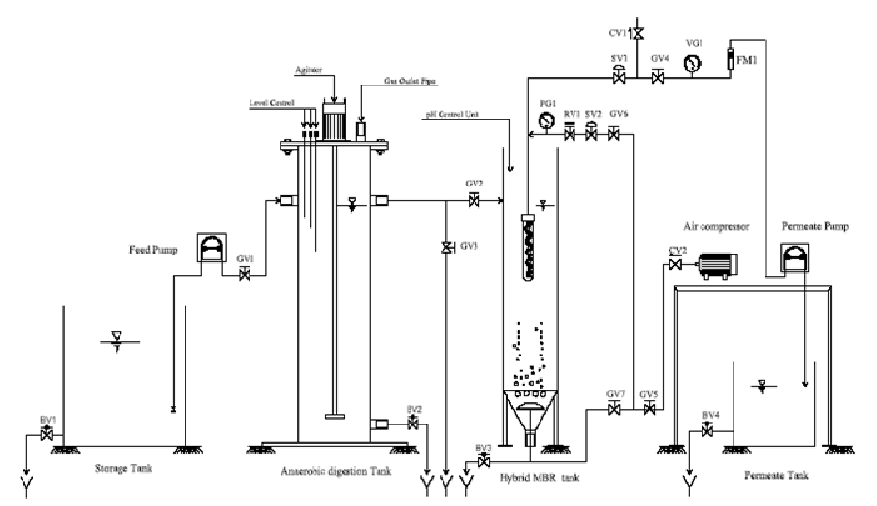

Fig. 1. Scheme of the experimental plant.

\section{Analytical Methods}

Performances of the reactors were analyzed for COD, BOD, TKN, Nitrite, Nitrate, TP, color and MLVSS according to the Standard Methods [9]. The carbonaceous material characterizations were measured in terms of COD parameter and were subdivided into a number of fractions [10]. Protein and carbohydrate were analyzed using Lowry method [11] and phenolic sulfuric acid method [12] with Bovine Serum Albumin (BSA) and glucose, respectively used as the standards.

\section{Membrane Resistance}

Membrane resistance was analyzed using Darcy's law as follows [13]:

$$
R_{T}=R_{m}+R_{c}+R_{p}=\frac{\mathrm{TMP}}{\mu \cdot \mathrm{J}}
$$

where $J$ is the filtration flux $\left[\mathrm{m}^{3} / \mathrm{m}^{2} \cdot \mathrm{s}\right]$, TMP is a transmembrane pressure $\left[\mathrm{kg} / \mathrm{m} \cdot \mathrm{s}^{2}\right]$ and $\mu$ is a dynamic viscosity of water $[\mathrm{kg} / \mathrm{m} \cdot \mathrm{s}] . R_{T}$ is a total resistance, $R_{m}$ is membrane resistance, $R_{c}$ is a concentration polarization and gel resistance, and $R_{p}$ is the pore blocking resistance by organic and inorganic matter [13].

TABLE II: RATIO OF FILTRATION OF FILTRATION RESISTANCE OF HMBR AND MBR SYSTEM.

\begin{tabular}{|l|c|c|}
\hline \multicolumn{1}{|c|}{ Condition } & Resistance $\left(10^{12} \mathrm{~m}^{-1}\right)$ & Ratio of $\mathrm{R}_{\mathrm{t}}(\%)$ \\
\hline $\mathrm{MBR}$ & & \\
\hline $\mathrm{R}_{\mathrm{m}}$ & 1.4372 & 22.93 \\
\hline $\mathrm{R}_{\mathrm{C}}$ & 3.5687 & 56.94 \\
\hline $\mathrm{R}_{\mathrm{f} \text { (Organic) }}$ & 0.9876 & 15.76 \\
\hline $\mathrm{R}_{\mathrm{f} \text { (Inorganic) }}$ & 0.2741 & 4.37 \\
\hline $\mathrm{R}_{\mathrm{t}}$ & 6.2676 & 100.00 \\
\hline $\mathrm{HMBR}$ & & \\
\hline $\mathrm{R}_{\mathrm{m}}$ & 1.1063 & 27.22 \\
\hline $\mathrm{R}_{\mathrm{C}}$ & 1.8700 & 46.02 \\
\hline $\mathrm{R}_{\mathrm{f} \text { (Organic) }}$ & 0.8901 & 21.90 \\
\hline $\mathrm{R}_{\mathrm{f} \text { (Inorganic) }}$ & 0.1973 & 4.86 \\
\hline $\mathrm{R}_{\mathrm{t}}$ & 4.0637 & 100.00 \\
\hline
\end{tabular}

\section{RESUlTS AND DisCUSSION}

\section{A. Effect of AC Addition on Filtration Performance}

The filtration operations were terminated simultaneously for both systems when the TMP reached until maximum stable and permeate flow decreased. Fig. 2 a. and b. show the change in TMP and flux over time for the experiments in HMBR system (with $715 \mathrm{mg} / \mathrm{L} \mathrm{AC)}$ ) and MBR system (without AC). For a cycle maintained at $11 \mathrm{~L} / \mathrm{m}^{2} . d$, the TMP change due to $\mathrm{AC}$ addition was lagging at about 2 times compared to the system without AC and had total hydraulic resistance lower than the MBR system about $35.2 \%$ as shown in Table II [14]-[17]. Irreversible fouling arisen from interactions of some dissolved and colloid matter on membrane could be removed by physical and chemical cleaning with external fouling rate of $3.21 \times 10^{-3} \mathrm{mbar} / \mathrm{min}$ and $6.35 \times 10^{-3} \mathrm{mbar} / \mathrm{min}$ for HMBR and MBR, respectively. $\mathrm{AC}$ addition in HMBR had concentration polarization resistance of $1.87 \times 10^{12} \mathrm{~m}^{-1}$, which is 1.9 times lower than MBR. This corresponds with increasing TMP and irreversible fouling (about $46.0-56.9 \%$ of total resistance). Therefore, addition of activated carbon in MBR can reduce reversible fouling through scouring effect; as a result the cake layer is incompressible and can prolong operation [16]. Chemical cleaning cannot remove irrecoverable fouling, which is clogging in membrane pore. However, HMBR havd irrecoverable fouling rate of $2.38 \times 10^{-5} \mathrm{mbar} / \mathrm{min}$ which is 6.8 times lower than MBR $\left(1.62 \times 10^{-4} \mathrm{mbar} / \mathrm{min}\right)$, and had internal fouling $16.03 \%$ lower than MBR. The results of soluble protein and carbohydrate as foulant in HMBR system were $7.21 \mathrm{mg} / \mathrm{g}$ VSS and $7.78 \mathrm{mg} / \mathrm{g}$ VSS, respectively, which are $0.11 \%$ and $9.01 \%$, lower than those MBR. The difference is because activated carbon can absorb dissolved organic compound in bulk solution [6], [7], [14], and therefore absorbs the foulant in membrane pore as the cause of internal irrecoverable fouling.

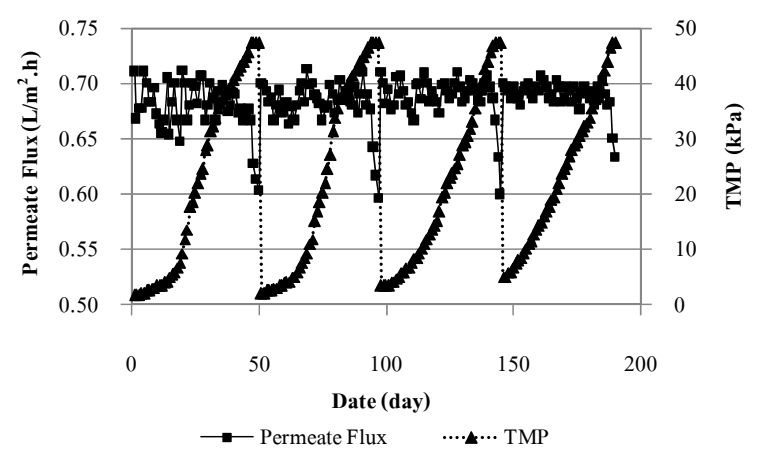

a) Membrane Bioreactor (MBR)

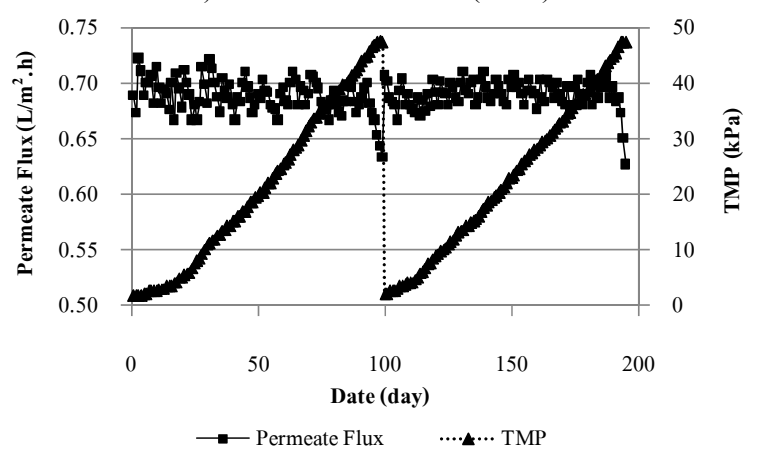

b) Hybrid Membrane Bioreactor (HMBR)

Fig. 2. Permeate flux and TMP profile a) membrane bioreactor and b) hybrid membrane bioreactor. 


\section{B. Effect of AC Addition of Organic Matter and Nutrient Removal}

Water quality and COD fraction of textile wastewater in anaerobic digestion, HMBR and MBR effluent are shown in Table III and Table IV. Textile wastewater had low $\mathrm{BOD} / \mathrm{COD}$ ratio of 0.15 and high soluble inert $\left(\mathrm{S}_{\mathrm{I}}\right)$ ratio at $60.7 \%$ of TCOD, which is considered as hardly biodegradable. This is caused by azo dyes' characteristic of being highly soluble in water solution. The structure of azo dyes is more complex and large molecule; therefore it has low biodegradability for heterotroph bacteria. However, anaerobic digestion can hydrolysis restricted biodegradable matter through absorption on microorganism surface and/or dead cell composition [17]. This caused $\mathrm{S}_{\mathrm{I}}$ to reduce $93.5 \%$. The anaerobic effluent have BOD/COD ratio 0.43 higher than influent. This implies that the effluent is higher biodegradable than the influent. HMBR and MBR can collect microorganisms in order to support higher volumetric load than conventional system. The average total BOD removal for HMBR and MBR was $93.5 \%$ and $86.9 \%$, respectively. The HMBR achieved $7.1 \%$ higher removal capability than the parallel operating MBR because of the addition of activated carbon (AC) [14]. The HMBR effluent has readily biodegradable ratio less than MBR system because biological removal is better due to the increasing amount of microorganisms on AC surface and prolongation of contact time between the organic matter and the biomass [18], [19].

TABLE III: COD FRACTIONS OF THE TEXTILE WASTEWATER, ANAEROBIC, MBR AND HMBR EFFLUENT.

\begin{tabular}{|c|c|c|c|c|c|c|c|c|}
\hline \multirow{2}{*}{$\begin{array}{c}\text { COD } \\
\text { fraction }\end{array}$} & \multicolumn{2}{|c|}{$\begin{array}{c}\text { Textile } \\
\text { wastewater }\end{array}$} & \multicolumn{2}{c|}{ Anaerobic $_{\text {eff. }}$} & \multicolumn{2}{c|}{ MBR $_{\text {eff. }}$} & \multicolumn{2}{c|}{ HMBR $_{\text {eff. }}$} \\
\cline { 2 - 10 } & $\begin{array}{c}\text { COD } \\
(\mathrm{mg} / \mathrm{L})\end{array}$ & $\begin{array}{c}\% \text { of } \\
\text { TCOD }\end{array}$ & $\begin{array}{c}\text { COD } \\
(\mathrm{mg} / \mathrm{L})\end{array}$ & $\begin{array}{c}\% \text { of } \\
\text { TCOD }\end{array}$ & $\begin{array}{c}\text { COD } \\
(\mathrm{mg} / \mathrm{L})\end{array}$ & $\begin{array}{c}\% \text { of } \\
\text { TCOD }\end{array}$ & $\begin{array}{c}\text { COD } \\
(\mathrm{mg} / \mathrm{L})\end{array}$ & $\begin{array}{c}\% \text { of } \\
\text { TCOD }\end{array}$ \\
\hline $\mathrm{S}_{\mathrm{S}}$ & 107.20 & 10.72 & 52.40 & 20.43 & 9.70 & 12.63 & 19.70 & 23.34 \\
\hline $\mathrm{X}_{\mathrm{S}}$ & 42.90 & 4.29 & 57.20 & 22.30 & - & - & - & - \\
\hline $\mathrm{S}_{\mathrm{I}}$ & 606.80 & 60.68 & 70.30 & 27.41 & 67.10 & 87.37 & 64.70 & 76.66 \\
\hline $\mathrm{X}_{\mathrm{I}}$ & 243.10 & 24.31 & 76.60 & 29.86 & - & - & - & - \\
\hline
\end{tabular}

TABLE IV: WATER QUALITY AND EFFICIENCY OF TEXTILE WASTEWATER TREATED BY ANAEROBIC DIGESTION, MBR AND HMBR

\begin{tabular}{|c|c|c|c|c|c|c|}
\hline \multirow{2}{*}{ Parameter } & \multicolumn{2}{|c|}{ Anaerobic $_{\text {eff. }}$} & \multicolumn{2}{|c|}{$\mathbf{M B R}_{\text {eff. }}$} & \multicolumn{2}{|c|}{ HMBR $_{\text {eff. }}$} \\
\hline & $(\mathrm{mg} / \mathrm{L})$ & \% removal & $(\mathrm{mg} / \mathrm{L})$ & \% removal & $(\mathrm{mg} / \mathrm{L})$ & \% removal \\
\hline TCOD & $256.5 \pm 27.1$ & $69.2 \pm 1.7$ & \multirow{2}{*}{$76.8 \pm 15.4$} & \multirow{2}{*}{$90.8 \pm 1.8$} & \multirow{2}{*}{$84.4 \pm 10.2$} & \multirow{2}{*}{$89.8 \pm 0.9$} \\
\hline SCOD & $122.7 \pm 11.0$ & $82.8 \pm 0.7$ & & & & \\
\hline $\mathrm{TBOD}_{20}$ & $109.6 \pm 5.0$ & $27.0 \pm 0.2$ & \multirow{2}{*}{$9.7 \pm 1.7$} & \multirow{2}{*}{$93.5 \pm 0.2$} & \multirow{2}{*}{$19.7 \pm 2.0$} & \multirow{2}{*}{$86.9 \pm 0.4$} \\
\hline $\mathrm{SBOD}_{20}$ & $52.4 \pm 6.7$ & $51.1 \pm 0.8$ & & & & \\
\hline TKN & $6.9 \pm 0.3$ & $20.8 \pm 7.2$ & $1.5 \pm 0.6$ & $77.8 \pm 8.5$ & $2.5 \pm 1.2$ & $63.6 \pm 7.2$ \\
\hline $\mathrm{TP}$ & $2.2 \pm 0.03$ & $55.4 \pm 0.6$ & $0.7 \pm 0.1$ & $68.2 \pm 2.6$ & $0.9 \pm 0.1$ & $59.1 \pm 2.7$ \\
\hline Color $^{*}$ & $1240.7 \pm 81.8$ & $43.1 \pm 1.5$ & $151.6 \pm 11.3$ & $87.2 \pm 4.1$ & $153.7 \pm 20.4$ & $87.0 \pm 8.5$ \\
\hline
\end{tabular}

Remark: *ADMI unit

\section{Nitrogen Removal by Nitrification-Denitrification}

Nitrogen can be removed by assimilation and nitrification-denitrification processes. However, TN removal efficiency operated at prolonged SRT was ignored in cell assimilation discussion [20]. Average nitrification rate was determined using $\mathrm{NH}_{4}{ }^{+} \mathrm{N}$ removal. The nitrification rate was calculated according to Eq. (3).

$$
\mathrm{r}_{\text {nitrification }}=\frac{\mathrm{Q}_{\text {in }}\left(\mathrm{NH}_{4}^{+}-\mathrm{N}_{\text {influent }}-\mathrm{NH}_{4}^{+}-\mathrm{N}_{\text {effluent }}\right)}{\mathrm{V}_{\text {reactor }}}
$$

The denitrification rate was calculated according to Eq. (4)

$$
\mathrm{r}_{\text {denitrification }}=\frac{\mathrm{Q}_{\text {in }}\left(\mathrm{TN}_{\text {influent }}-\mathrm{TN}_{\text {effluent }}\right)}{\mathrm{V}_{\text {reactor }}}
$$

Nitrogen removal pathway was shown in Table V. The HMBR and MBR had nitrification rates of $5.39 \mathrm{mg} / \mathrm{L} . \mathrm{d}$ and $4.41 \mathrm{mg} / \mathrm{L} . \mathrm{d}$, respectively. HMBR system can remove nitrogen better than MBR. This is because the carbon source for heterotrophic bacteria remained in HMBR is lower than in MBR system therefore the nitrifying bacteria can oxidize ammonia nitrite/nitrate better than in MBR [20]. The dinitrification rates of HMBR and MBR were $5.39 \mathrm{mg} / \mathrm{L} . \mathrm{d}$ and $4.38 \mathrm{mg} / \mathrm{L} . \mathrm{d}$, respectively. Results showed that the denitrification rate of HMBR is higher than MBR. This is the result of AC in HMBR system that has a biofilm system on the surface, which makes it less efficient for oxygen to transfer through the biofilm and creates an anoxic condition inside the porous structure of the biofilm [21], [22].

TABLE V: AMMONIA AND ORGANIC NITROGEN, NitRITE AND NitRATE

\begin{tabular}{|l|c|c|c|c|}
\hline \multicolumn{1}{|c|}{ Sample } & Textile & Anaerobic $_{\text {eff. }}$ & MBR $_{\text {eff. }}$ & HMBR $_{\text {eff. }}$ \\
\hline $\begin{array}{l}\text { Ammonia } \\
\text {-N }\end{array}$ & $0.70 \pm 0.20$ & $0.63 \pm 0.10$ & - & - \\
\hline $\begin{array}{l}\text { Organic- } \\
\mathrm{N}\end{array}$ & $8.05 \pm 1.09$ & $6.30 \pm 0.20$ & $2.52 \pm 1.19$ & $1.54 \pm 0.59$ \\
\hline TKN & $8.75 \pm 1.29$ & $6.93 \pm 0.30$ & $2.52 \pm 1.19$ & $1.54 \pm 0.59$ \\
\hline Nitrite & $\begin{array}{c}0.0318 \pm 0.00 \\
01\end{array}$ & $\begin{array}{c}0.0054 \pm 0.00 \\
02\end{array}$ & $\begin{array}{c}0.0023 \pm 0.00 \\
04\end{array}$ & $\begin{array}{c}0.0015 \pm 0.00 \\
03\end{array}$ \\
\hline Nitrate & $\begin{array}{c}0.0623 \pm 0.00 \\
60\end{array}$ & $\begin{array}{c}0.0188 \pm 0.00 \\
27\end{array}$ & $\begin{array}{c}0.0236 \pm 0.00 \\
04\end{array}$ & $\begin{array}{c}0.0222 \pm 0.00 \\
32\end{array}$ \\
\hline TN & $8.84 \pm 1.30$ & $6.95 \pm 0.30$ & $2.55 \pm 1.19$ & $1.56 \pm 0.59$ \\
\hline
\end{tabular}

\section{CONCLUSION}

Due to AC addition, HMBR can be operated longer than MBR. AC can reduce the concentration of polarization fouling through scouring effect and adsorbing of foulant; it causes the internal fouling to be lower than external fouling. HMBR achieves higher removal capacity in terms of COD, $\mathrm{BOD}$, nitrogen, phosphorus and color. The $\mathrm{AC}$ added can absorb the organic matter and nutrients. Furthermore, the $\mathrm{AC}$ as media for microorganism attachment enhances degradability of organic and nutrients. HMBR can also remove nitrogen by nitrification and denitrification reaction though anoxic condition inside the porous structure of the 
biofilm, which occurs because oxygen cannot transfer into the biofilm on AC surface.

\section{ACKNOWLEDGMENT}

This work was supported by Suranaree University of Technology and Thailand Institute of Scientific. We would like to thank the staff for their continual assistance in preparing and carrying out this research in the Institute of Environmental Engineering, Suranaree University of Technology.

\section{REFERENCES}

[1] J. G. Choi, T. H. Bae, J. H. Kim, T. M. Tak, and A. A. Randall, "The behavior of membrane fouling initiation on the crossflow membrane bioreactor system," Journal of Membrane Science, vol. 203, pp. 103-113, 2002.

[2] T. Stephenson, S. J. Judd, B. Jefferson, and K. Brindle, Membrane Bioreactors for Wastewater Treatment, IWA Publishing, London, 2000.

[3] A. Drews, "Membrane fouling in membrane bioreactorsCharacterisation, contradictions, cause and cures," Journal of Membrane Science, vol. 363, pp. 1-28, 2010.

[4] D. Jeison and J. B. Van Lier, "On-line cake-layer management by trans-membrane pressure steady state assessment in anaerobic membrane bioreactors for wastewater treatment," Biochemical Engineering Journal, vol. 29, pp. 204-209, 2006.

[5] S. Ognier, C. Wisniewski, and A. Grasmick, "Membrane bioreactor fouling in sub-critical filtration condition: a local critical flux concept," Journal of Membrane Science, vol. 229, pp. 171-177, 2004.

[6] W. Guo, S. Vigneswaran, H. H. Ngi, W. Xing, and P. Goteti, "Comparison of the performance of submerged membrane bioreactor (SMBR) and submerged membrane adsorption bioreactor (SMABR)," Bioresource Technology, vol. 99, 1012-1017, 2008.

[7] F. J. Hai, K. Yamamoto, F. Nakajima, and K. Fukushi, "Removal of structurally different dyes in submerged membrane fungi reactorBiosorption/PAC-adsorption, membrane retention and biodegradation," Journal of Membrane Science, vol. 325, pp. 395-403, 2008.

[8] Metcalf and Eddy, Wastewater Engineering: Treatment Disposal Reuse, 4th ed, New York: USA, McGraw-Hill, 2003.

[9] APHA, AWWA, and WEF, Standard methods for the examination of the water and wastewater, Washington D.C.: American Public Health Association, 2005.

[10] M. Wentzel, A. Mbewe, M. Lakay, and G. Ekama, "Batch test for characterization of the carbonaceous materials in municipal wastewater," Water Research, vol. 25, no. 2, pp. 327-335, 1999.

[11] O. H. Lowry, N. J. Rosebrough, A. L. Farr, and R. J. Randall, "Protein measurement with the Folin-Phenol reagents," J. Biol. Chem., vol. 193, pp. 265-275, 1951.
[12] M. Dubois, K. A. Gilles, J. K. Hamilton, R. A. Rebers, and F. Smith, "Colorimetric method for the determination of sugars and related substances," Analytical Chemistry, vol. 28, no. 3, pp. 350-356, 1956.

[13] Z. Zheng, M. Ernst, and M. Jekel, "Identification and quantification of major organic foulants in treated domestic wastewater affecting filterability in dead-end ultrafiltration," Water Research, vol. 43, pp. 238-244, 2009.

[14] Y. Z. Li, Y. L. He, Y. H. Liu, and S. C. Yang, "Comparison of the filtration characteristics between biological powdered activated carbon sludge and activated sludge in submerged membrane bioreactors," Desalination, vol. 174, pp. 305-314, 2005.

[15] Z. Ying, and G. Ping, "Effect of powdered activated carbon dosage on retarding membrane fouling in MBR," Separation and Purification Technology, vol. 52, pp. 154-160, 2006.

[16] Y. Satyawali and M. Balakrishnan, "Performance enhancement with powered activated carbon (PAC) addition in a membrane bioreactor (MBR) treating distillery effluent," Journal of Hazardous Materials, vol. 170, pp. 457-465, 2009.

[17] W. J. Ng, T. S. Sim, S. L. Ong, K. Y. Ng, M. Ramasamy, and K. N. Tan, "Sequencing batch reactor (SBR) removal of toxicity from combined sewage," Bioresource Technology, vol. 47, no.2, pp. 107-112, 1994.

[18] N. Lesage, M. Sperandio, and C. Cabassud, "Study of a hybrid process: Adsorption on activated carbon/membrane bioreactor for the treatment of an industrial wastewater," Chemical Engineering and Processing, vol. 47, pp. 303-307, 2008.

[19] J. Y. Tian, H. Liang, Y. L. Yang, S. Tian, and G. B. Li, "Membrane adsorption bioreactor (MABR) for treating slightly polluted surface water supplies: As compared to membrane bioreactor (MBR)," Journal of Membrane Science, vol. 325, pp. 262-270, 2008.

[20] Z. Fu, F. Yang, F. Zhou, and Y. Xue, "Control of COD/N ratio for nutrient removal in a modified membrane bioreactor (MBR) treating high strength wastewater," Bioresource Technology, vol. 100, pp. 136-141, 2009.

[21] A. Hille, M. He, C. Ochmann, T. Neu, and H. Horn, "Application of two component biodegradable carriers in a particle-fixed biofilm airlift suspension reactor: development and structure of biofilms," Bioprocess and Biosystem Engineering, vol. 32, no. 1, pp. 31-39, 2009.

[22] E. Walters, A. Hille, M. He, C. Ochmann, and H. Horn, "Simultaneous nitrification/denitrification in a biofilm airlift suspension (BAS) reactor with biodegradable carrier material," Water Research, vol. 43, no. 18, pp. 4461-4468, 2009.

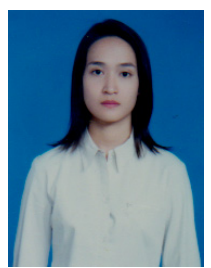

Wimonmas Boonyungyuen follows a Bachelor's Degree in Civil Engineering and Master's Degree in Environmental Engineering. And now she is a graduate student in Environmental Engineering of Suranaree University of Technology, NakhonRatchasima, Thailand. My researches interested are in biological wastewater treatment. 